\title{
COGNITIVE REPRESENTATION OF SITUATIONAL AND PROPOSITIONAL TIME FLOW AS BASIS FOR TEMPORAL FRAMING EFFECT IN FUTURE TIME MODE
}

\author{
Olexiy POLUNIN ${ }^{1}$ \\ Visiting researcher at the Copernicus Center for Interdisciplinary Studies \\ ul. Slawkovska 17, 31-016 Cracow, Poland \\ Permanent affiliation: Institute of Social and Political Psychology \\ vul. Andriivska 15, Kyiv, 04070 Ukraine \\ E-mail: polunin-alex@yandex.ru
}

\begin{abstract}
The paper presents a finding of new kind of the temporal framing effect, which is applied to a monetary saving proposition. Based on our previous assumption about the multiple cognitive representations of time flow (Polunin, 2009, 2011, 2013), two temporal processes were assumed - situational and propositional time flow. Each of these temporal processes has specific features, and differently impacts the evaluation of money proposed for saving. In two experiments subjects made decisions on a monetary saving proposition. Despite the equal distance to the beginning of the saving possibility and the equality of the saving amounts a temporal framing effect arises. The subjects made significantly different decisions depending on whether a situational or a propositional time flow was activated. The first one induces a slow decline of positive responses to a saving proposition while the second one leads to a strong loss of attractiveness of a saving proposition.
\end{abstract}

Key words: decision-making, framing, temporal framing, situational future, propositional future

\section{Introduction}

Over the last few decades the studies of "framing effects" in the area of human decision-making have expanded and include such domains as cognition, psycholinguistics, perception, social psychology, health psychology, clinical psychology, and business (overviews by Levine, Schneider, \& Gaeth, 1998; Kühberger, 1998). The studies

\footnotetext{
${ }^{1}$ The research stay at the Copernicus Center and the publication were supported by the John Templeton Foundation Grant "The Limits of Scientific Explanation".
}

on temporal framing effect within the intertemporal decision-making are also presented by a number of publications (Chandran \& Menon, 2004; Loewenstein, 1988; Loewenstein \& Elster, 1992; Mazur, 1987; Prelec \& Loewenstein, 1997). Therefore, it is difficult to find an experimental set which results in a new kind of non-described framing effect. But looking at the conventional approach to studies on intertemporal decision-making one can notice that time flow is represented as a singular, homogeneous process correlated with a growing waiting interval, and such process is equal for all objects and situations (Frederick et al., 2002; Loewenstein \& Elster, 1992; Loewenstein \&

DOI: $10.21909 /$ sp.2015.01.670 
Prelec 1992). This approach dates back to the very early publication by Samuelson (1937), who proposed the discounting utility model (DU model). The DU model generalizes an intertemporal choice and specifies a subject's intertemporal preferences over consumption profiles. Its central idea is that all of the disparate motives underlying intertemporal choice can be condensed into a single parameter - the discount rate. In later modifications of the DU model, one can find the discussions on the parameters of equation, describing value discounting, e.g., whether it is truly hyperbolic. Not only in the DU-model but also in the general scientific paradigm and in different fields of economics, time is considered as an abstract category with time line representing a singular temporal process. On the other hand, when it concerns human made intertemporal decisions the peculiarities of time processing by the human mind must be taken into account for a more realistic modelling. The well-known discrepancy between subjective interval production and interval reproduction, shown by Fraisse (1985) and modelled by Block and Zakay (1996), points to the possible anisotropy of a subjective time line. One also has to consider the possible interferences between the processing of temporal and non-temporal information in working memory, which can be a factor in intertemporal decision-making. Moreover, psychological studies on time processing show the divergence between the flow of abstract physical time and subjective human time experience (Fraisse, 1985; Block \& Zakay, 1997; Thomas \& Weaver, 1975; Wearden, 2002).

Construal Level Theory (CLT; Liberman \& Trope, 1998; Trope \& Liberman, 2000) suggests that people have very distinct psycho- logical associations with temporal distances. In other words, alternatives are evaluated differently at different points in time. The peculiarities of the human time processing let us assume that our mind has the capability of developing more than one cognitive representation for a temporal process running at one and the same time distance. Block (1978, 1990) proposed a contextual-change hypothesis and developed a model for time processing, which is based upon the context generation. Later, Block and Zakay (1997) provided an attention-based model for time processing, where timing is modelled for the duration of a certain event and not for a context as whole. Our studies (Polunin, 2009, 2011a, 2011b, 2013) show that the temporal dimension of decision-making is a complex one and includes a multitude of temporal processes. Each of them has its own cognitive representation, which reflects a specific development of an object over time and a corresponding change of the object's value. If we assume that the human mind is able to develop more than one cognitive representation for time flow at one and the same time interval, it is also necessary to assume that one and the same proposition can be differently evaluated over one and the same timedistance and even from one and the same reference point, e.g., from the present time moment. Thus, we can expect that applying different representations of time flow to the same monetary saving proposition will result in different cognitive representations of such a proposition. Consequently, the discrepancy in the proposition evaluation should lead to different decision outcomes. It means that a subject should value differently one unit of money (e.g., 1EUR) over one and the same time-distance, depending on the activated temporal process. 
Based on our study on a temporal framing ofelectoral decision-making(Polunin, 2010), we distinguish cognitive representations for propositional and situational future. The propositional future means a time perspective when time flow is considered only for an object (a proposition). Under situational future we understand a general future, a cognitive representation of a situation as a whole at any moment in future time mode. Mathematically, there is no difference between these two kinds of futures, as long as the time distance from the reference moment to the future moment is the same. But based on the wording of the task it should be possible to activate separately the propositional and situational future. Thus, the hypothesis is that the situational and propositional future are represented by two different temporal processes, and based on their discrepancy, the temporal framing effect is to be expected when the same amount of money is proposed to be saved at the same physical time distance.

We are going to focus attention of the subject once at the time of a distance from the gain and the other time at the moment of gain. This should lead to activation of cognitive representations correspondingly for propositional vs. situational time flow. If we succeed in providing conditions when two different cognitive representations of time flow are employed at the same time distance, we may expect manifestation of temporal framing. More specifically, while objectively the waiting for monetary saving refers to the same time period, the use of temporal reference frames, such as situational or propositional time flow, is likely to trigger cognitive representations of time flow that result in a temporal framing effect.

When different decisions are made on mathematically equal propositions, one can argue that two different cognitive representations of them are available. Such discrepancy in decision outcomes is known as the framing effect. The overviews on different kinds of framing effects by Levine, Schneider and Gaeth (1998), and Kühberger (1998) describe a list of conditions when a framing effect arises. Levine, Schneider and Gaeth (1998) describe a taxonomy composed of three different types of framing manipulations: risky choice framing, attribute framing, and goal framing. The standard risky choice framing effect was introduced by Tversky and Kahneman (1981) and it illustrates how the different descriptions of proposition riskiness affect a decision outcome. Attribute framing shows how an evaluation of an object or event characteristics serves as the focus of framing manipulation and finally impacts on the decision outcome. In a goal framing, the goal of an action or behavior is framed in different ways influencing the decision made.

There are also decisions made when the time-parameter is manipulated, and the temporal framing effect arises. In some cases, it is manifested due to the difference in processing of the time distance between two propositions or in the order of propositions processing (Loewenstein, 1988), or because of different time horizons applied in tasks wording (Chandran \&Menon, 2004). The list of the above mentioned framing effects does not include thekind of temporal framing, when a subject makes different decisions on mathematically equal saving propositions or another kind of gain, which is proposed at the same time-moment, at thesame time-distance from the present time moment, and propositions are processed in the same order, namely from the present to the future. These conditions can be demonstrated by Figure 1 . 


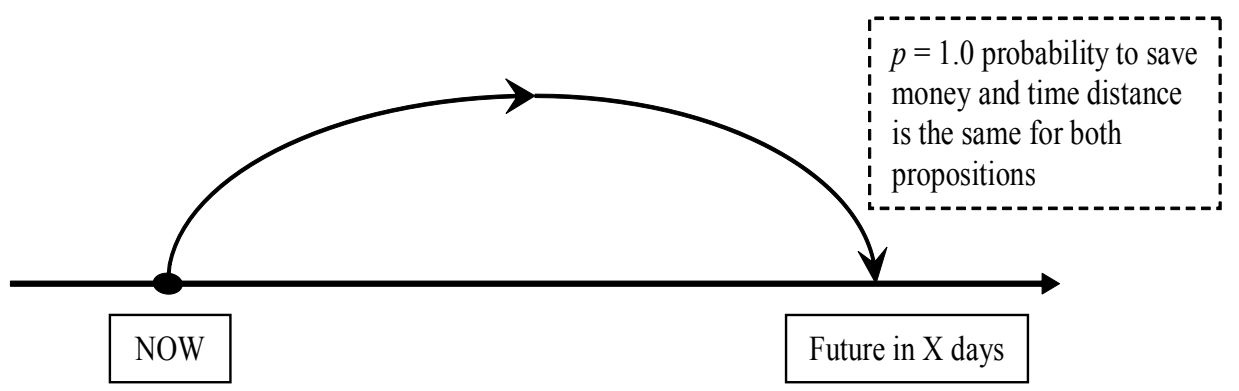

Figure 1 Schematic description of saving proposition in future time mode. Once saving is formulated as a future situation and the other time - as propositional future saving. The "Now" is the reference time moment when a saving proposition is made to a subject. The interval between "now" and "future in X days" is the waiting time for the realization of both saving propositions. The $p$ is a probability to save money in $\mathrm{X}$ days on sale, which equals to 1 for both task formulations.

The category of temporal framing is already in use. Loewenstein (1988) in his article "Frames of mind in intertemporal choice" demonstrates the applicability of the reference point concept (Markowitz, 1952; Bell, 1982) to intertemporal choice, and compares it to the Prospect Theory proposed by Kahneman and Tversky's (1979). Loewenstein (1988) describes three ways to elicit an individuals' relative preferences for immediate versus delayed consumption: neutral, delay, speed-up. One way is to, ask a subject to specify the most s/he would pay to obtain an object immediately (the immediate price) and then ask how much s/he would pay to get the object following a time delay (the delayed price). Secondly, one can ask how much the subject would pay to obtain the object immediately, instruct him/her to imagine that $\mathrm{s} / \mathrm{he}$ has made the purchase, and then ask for the smallest amount $\mathrm{s} / \mathrm{he}$ would accept in order to delay consuming. In the third way, the speed-up situation, an individual anticipates future possession and contemplates speeding it up, for example, by paying more money for the item. One instructs a subject to imagine that $\mathrm{s} / \mathrm{he}$ has paid certain amount for future consumption, and then ask for the most s/he would be willing to pay to speed up consumption so as to eliminate the delay. In all of these three cases it is about a comparison between the immediate consumption price and the delayed consumption price. We are going to demonstrate a framing effect, when the difference in decision outcomes arises from two saving propositions which are processed in the same order, are equal in amount, equally delayed and belonging to the same time moment in the future.

Chandran and Menon (2004) also write about temporal framing. They have used the "every day" and "every year" frames and shown that every day framing makes risks appear more proximal and concrete than every year framing. In their opinion two different temporal frames - every day and every year - should objectively refer to same time 
period (i.e., the present). Without discussing here the psychological borders of subjective present time, it is worth underlining that "a day" and "a year" are far away, they are not equal time intervals and not the same time markers. Moreover, Chandran and Menon (2004) refer more to different time horizons than time distances. This is why the temporal framing by Chandran and Menon (2004) differs fundamentally from the one studied here, when the equality of both, time distance and saving amount, are preserved.

According to the discounting utility model (Samuelson, 1937), no framing effect should be expected as long as in both task formulations the saving amount, the time moment when the proposition is made, and the time distance to the realization of monetary saving (win) are the same. Thus, the assumed kind of temporal framing effect could represent a new anomaly of the DUmodel, among others described earlier (Frederick et al., 2002; Loewenstein, 1988; Loewenstein \& Prelec, 1992; Read et al., 2005).

\section{EXPERIMENT 1}

\section{Method}

The experimental task involved a problem situation in which a student was going to buy a computer. The proposed monetary saving was $99 \mathrm{UAH}^{2}$. In one wording of the problem, the whole situation was moved to 4 days in the future. In the other

\footnotetext{
${ }^{2}$ UAH or Ukrainian hryvna, 99 UAH equals approximately 12.2 USD or 9.56 EUR. At the time of data collection the exchange rate was: 1USD $=8.06-8.14 \mathrm{UAH}$ and $1 \mathrm{EUR}=10.28-10.41 \mathrm{UAH}$.
}

wording of the problem, only the beginning of the saving opportunity was 4 days in the future, while the situation itself was occurring in the present time mode. Thus, the independent variable has two grades: situational vs. propositional future monetary saving. The absolute (99 UAH), and relative (3.1\%) saving, and the initial price of the computer (3199 UAH) were the same in both wordings. Two groups of subjects made decisions on whether they accept the saving proposition. Each group got only one wording of the decision problem. The between subjects experimental design was utilized, which is usual for such studies (Tversky \& Kahneman, 1981; Kühberger, 1998; Levin et al., 1998).

\section{Materials}

Written versions of the problem were prepared in Ukrainian. A similar wording was used in each case and just the time marks were set once on a situation as whole and the other time on the saving proposition. In both task wordings the time distance was underlined to make it more explicit. The participants were asked to mark their decision by marking the corresponding box.

\section{Task for activation of situational time flow}

Imagine the following situation and decide how you will act.

Please imagine that in 4 days you will go to the electronics store to purchase a notebook computer for $3199 \mathrm{UAH}$. When you pick out a notebook computer and you go to the cashier, a shop assistant informs you that the notebook you wish to buy is on sale for $3100 \mathrm{UAH}$ at the other branch of the store, located 20 minutes drive away. 
Would you make the trip to the other store? (check one box)

\section{YES $\square \quad \mathrm{NO} \square$ flow \\ Task for activation of propositional time}

Imagine the following situation and decide how you will act.

Please imagine that you go to an electronics store and are about to purchase a notebook computer for 3199 UAH. When you pick out a notebook computer and you go to the cashier, a shop assistant informs you that the notebook you wish to buy will be on sale for $3100 \mathrm{UAH}$ in 4 days at the other branch of the store, located 20 minutes drive away.

Would you make the trip to the other store? (check one box)

$$
\text { YES } \square \quad \mathrm{NO} \square
$$

\section{Subjects}

162 students (81 subjects for each experimental condition) between the ages of 18 and 22 (mean age 19.9 years; $65 \%$ males and $35 \%$ females) participated in the experiment. The participation was voluntary and unpaid. The number per session ranged from 12 to 28 subjects. Each participant was randomly assigned to one of two experimental conditions.

\section{Results}

According to the mathematical description of the decision problem, each subject got the possibility to save the same amount of money (99 UAH) on the same day in the future (in 4 days). Only the wordings of the saving propositions were different. The standard discounting formulation implies that such delayed consumption must have equal values. But the number of positive responses $(57 \%)$ given to the saving proposition within the situational future is significantly higher than that for an equal monetary saving but given within the propositional future $(39 \%)$, Pearson $\chi^{2}=4.8 d f=1$, $p=0.028$. Thus, we can argue that at the level of cognitive representation, two essentially different temporal processes were activated: one for a situational future and the other for a propositional future. These temporal processes show different features at the same time distance and in relation to the same object (amount of money), therefore one must conclude that these temporal processes are different. Their discrepancy leads to different decision outcomes regarding the same monetary saving, and this is manifested as the temporal framing effect (Figure 2).

The manifestation of the temporal framing effect seems to be sensitive to the gender of subject. A separate analysis for the male subjects shows a significant framing effect (Pearson $\chi^{2}=5.46, p=0.019$ ), whereas for the female subjects it is Pearson $\chi^{2}<1$. Thus, the framing effect we found is based mostly on results of the male subjects. This finding can be explained by the type of commodity used in the task formulation. Possibly, a computer is a kind of a men-wishful-commodity. Thus, in the second experiment the role of the subject's gender in the manifestation of the temporal framing effect will be studied further. For this goal a commodity with more or less equal gender attractiveness will be used in the next experimental task, e.g., a pair of shoes. 


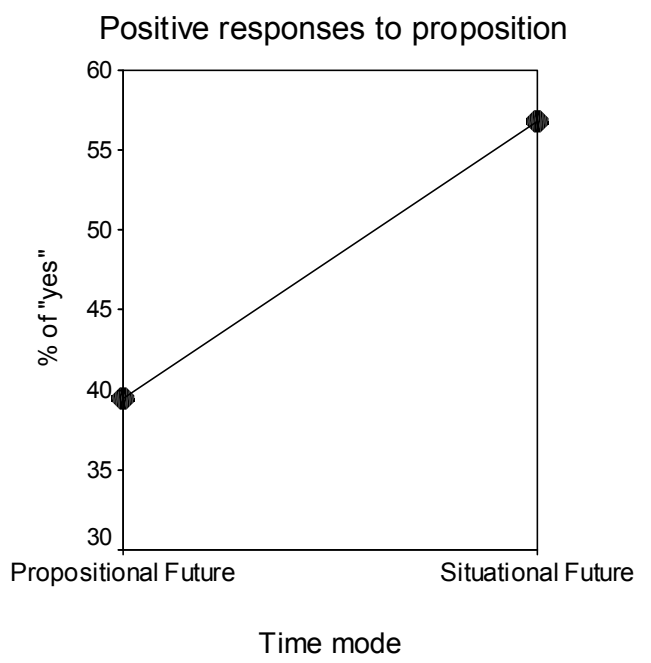

Figure 2 The temporal framing effect. Two equal monetary saving propositions lead to the significantly different percentage of positive answers (39\% and 57\% of "yes") depending on whether the time mark is set on a proposition or on a situation (Pearson $\chi^{2}=4.8$, $d f=1, p=0.028)$.

\section{EXPERIMENT2}

In order to replicate the found temporal framing effect a repeated study was carried out. Instead of a computer, a pair of shoes was proposed as the commodity to buy, in order to examine the possible gender effect, which seemed to have modulated the manifestation of the temporal framing effect in the first experiment. In this study we are going to examine a number of hypotheses. The first one is similar to the hypothesis from the first study: the situational and propositional futures are cognitively represented by two different temporal processes. Their discrepancy leads to different evaluations of one and the same monetary saving proposition, and correspondingly to different decisions that appear as the temporal framing effect (hypothesis 1). Additionally, we assume that these two temporal processes cause different loss of proposition attractiveness, in comparison to the present time condition, when a subject does not have to wait for saving money. Formally, hypothesis 1 can be given as inequality of the percentage of positive responses in each experimental condition:

YES(now) $>$ YES(situational future in $X$ days) $>$ YES(propositional future in $\mathrm{X}$ days).

The second hypothesis considers the role of time distance: if the cognitive representations of the situational and propositional future are independent and differ in their features, theymust result in different patterns of proposition attractiveness, and the growing timedistance mustmake this discrepancymore 
pronounced. Thus, for the longer time distance a stronger temporal framing effect is to be expected (hypothesis 2). For examining this divergence between the situational and propositional time flows, two time distances will be introduced, 4 days and 7 days in the future.

The third hypothesis aims to examine the difference between the situational and propositional time flow through their combined impact on the saving proposition. Hypothesis 3: If the situational and propositional time flows have different cognitive representations, their combined application to the same object (saving proposition) over the same time distance should lead to different decision outcomes. Each of them will have different partial contribution to the loss of attractiveness of monetary saving proposition. In order to examine this assumption, two experimental conditions will be introduced with an equal number of days when the propositional and situational time flow are activated. The 7 days-time-distance between the present time moment and the beginning of the sale is divided into $5+2$ days. Under one condition, it is the sum of 5 days of the situational future and 2 days of the propositional future. Under the other condition, it is the sum of 5 days of propositional future and 2 days of situational future. According to the features of subjective situational and propositional time flow the following result is to be expected:

YES(2 days sit. +5 days propos.) $<$ YES(5 days sit. +2 day propos.).

Moreover, Read (2001) has shown the subadditive effect in discounting over a delay, which means that the discounting is greater when the delay is divided into subintervals. Based on the subadditive effect, let us make an assumption opposite to hypothesis 1 , that the situational and proposi- tional time flow have the same cognitive representation and are to be described by the same features. Thus, according to the subadditive effect (Read, 2001), we should expect the following inequalities for the percentage of positive responses: YES(7 days sit.) $>$ YES(2 days sit. +5 days propos.), YES(7 days sit.) $>$ YES( 5 days sit. +2 days propos.), and also YES(7 days propos.) $>$ YES(5 days sit. + 2 days propos.), and YES(7 days propos.) $>\operatorname{YES}(2$ days sit. +5 days propos.). But according to our assumption, the situational discounting is less than the propositional one. Thus, because of inequality of situational and propositional time flows we indeed should expect: YES(7 days sit.) > YES(2 days sit. +5 days propos.), YES( 7 days sit.) $>$ YES(5 days sit. +2 day propos.). But for the propositional time flow the expectation is the opposite one, the subadditive effect must be broken: YES(7 days propos. $)<$ YES(5 days sit. +2 days propos.), and YES(7 days propos.) $<\operatorname{YES}(2$ days Sit. +5 days propos.).

\section{Method}

Written versions of the problem were prepared in Ukrainian. A similar wording was used as in the first experiment and just the commodity and the time marks differ. The following parameters of the saving proposition were used in the experiment: initial price of a pair of shoes was set at $560 \mathrm{UAH}$, the absolute saving equals to $40 \mathrm{UAH}$ (relative saving equals to $7.14 \%$ ), so the saving can be described by equation $560-40=520 \mathrm{UAH}^{3}$.

\footnotetext{
${ }^{3}$ During the data collection the current exchange rates were: $1 \mathrm{USD}=8.14-8.19 \mathrm{UAH}$, and $1 \mathrm{EUR}$ $=10.68-11.05 \mathrm{UAH}$. So, $40 \mathrm{UAH}$ equal approximately to 4.9 USD or 3.68 EUR.
} 
For the condition with the composed 7 days time distance the following task formulation was used:

Imagine the following situation and decide how you will act.

Please imagine that in 5 days you will go to the shop to purchase a pair of shoes for $560 \mathrm{UAH}$. When you pick out the shoes and you go to the cashier, a shop assistant informs you that the shoes you wish to buy will be on sale for $520 \mathrm{UAH}$ in 2 days at the other branch of the store, located 20 minutes drive away.

Would you make the trip to the other store? (check one box)

\section{YES $\square \quad \mathrm{NO} \square$}

Similarly, the task was formulated for the condition with 2 days of situational future and 5 days of propositional future. In all task wordings the time distance was underlined to make it more explicit. The design of the experiment and the expected results are given in Table 1.

\section{Subjects}

840 students ( 120 subjects for each experimental condition) between the ages of 17 and 26 (mean age 18.86 years; $65 \%$ males and $35 \%$ females) participated in the experiment. The participation was voluntary and unpaid. The number per session ranged from 16 to 34 subjects. Each participant was randomly assigned to one of the experimental conditions.

\section{Results}

The highest number of positive responses on the saving proposition was found for the present time condition (66.7\%), when the subject does not have to wait at all. The situational future produces less positive responses to a saving proposition, but it re-

Table 1 The design of the second experiment and expected results. The original price for pair of shoes was $560 \mathrm{UAH}$, absolute price reduction equals $40 \mathrm{UAH}$, the relative price cut equals $7.14 \%$.

\begin{tabular}{|c|c|c|c|c|c|c|}
\hline \multicolumn{7}{|c|}{ Experimental conditions with different time distances to the beginning of a sale } \\
\hline Now & $\begin{array}{l}4 \text { days of } \\
\text { situational } \\
\text { future }\end{array}$ & $\begin{array}{l}4 \text { days of } \\
\text { proposit. } \\
\text { future }\end{array}$ & $\begin{array}{l}7 \text { days of } \\
\text { situational } \\
\text { future }\end{array}$ & $\begin{array}{l}7 \text { days of } \\
\text { proposit. } \\
\text { future }\end{array}$ & $\begin{array}{c}5 \text { days of } \\
\text { situational } \\
\text { future and } 2 \\
\text { days of proposit. } \\
\text { future }\end{array}$ & $\begin{array}{c}2 \text { days of } \\
\text { situational } \\
\text { future and } 5 \\
\text { days of proposit. } \\
\text { future }\end{array}$ \\
\hline $\begin{array}{l}\text { A base-line } \\
\text { readiness to } \\
\text { save } 40 \\
\text { UAH }\end{array}$ & \multicolumn{2}{|c|}{$\begin{array}{c}\text { Temporal framing effect } \\
\text { similar to one from the } \\
\text { first study } \\
\text { (hypothesis 1) }\end{array}$} & \multicolumn{2}{|c|}{$\begin{array}{l}\text { A stronger temporal } \\
\text { framing effect is due to } \\
\text { the increased time } \\
\text { distance } \\
\text { (hypothesis 2) }\end{array}$} & \multicolumn{2}{|c|}{$\begin{array}{l}\text { A discrepancy in percentage of } \\
\text { "yes" responses between these two } \\
\text { conditions is to be expected, which } \\
\text { is due to the independence of } \\
\text { situational and propositional time } \\
\text { flows (hypothesis } 3 \text { ) }\end{array}$} \\
\hline
\end{tabular}


mains more similar to the present time condition than the propositional future. In other words, a subjective situational time flow leads to a smaller decrease of saving proposition value than the propositional one. The relation proposed in the first hypothesis, namely: YES(now) > YES(situational future in $X$ days) $>$ YES(propositional future in $X$ days) was found to be correct (Table 2). The temporal framing effect is also replicated for both time distances, 4 and 7 days. The second hypothesis assumed that with the growing time distance the discrepancy between the situational and propositional time flow will be more pronounced, which is supported by our data. A stronger temporal framing effect is found for the longer time distance. Moreover, for the situational and propositional time flows the decrease of "yes" responses calculated for every day of waiting is different. At the shorter time distance of 4 days, the situational time flow causes the loss of $4.18 \%$ per day, while for the propositional time flow it equals to $7.5 \%$ per day. For the 7 days time distance the loss of "yes" responses for situational time flow equals $2.3 \%$ per day, and for propositional $10.22 \%$ per day.

It is worth noticing that the propositional future causes a loss of proposition attractiveness with the growing time distance, which is in agreement with the classical DUmodel (Samuelson, 1937). On the other hand, the situational future tends to show a kind of different trend for the loss of proposition attractiveness, or at least this process is to be described by the different rate of discounting. This departure of the cognitive representation of situational time flow from the discounting utility model should be studied in future experiments. It appears that under the situational time flow a waiting process is not started as such, the subject almost "jumps over" the interval between the present time moment and the future day when the sale begins. Probably the situational future departs from the discounting model and represents a kind of declared readiness

Table 2 The results of the second experiment; percentage of "yes" responses to a saving proposition and size of the framing effect

\begin{tabular}{|c|c|c|c|c|c|c|c|}
\hline & Now & $\begin{array}{l}4 \text { days of } \\
\text { situat. } \\
\text { future }\end{array}$ & $\begin{array}{l}4 \text { days of } \\
\text { proposit. } \\
\text { future }\end{array}$ & $\begin{array}{l}7 \text { days of } \\
\text { situat. } \\
\text { future }\end{array}$ & $\begin{array}{l}7 \text { days of } \\
\text { proposit. } \\
\text { future }\end{array}$ & $\begin{array}{l}5 \text { days of } \\
\text { situat. } \\
\text { future and } \\
2 \text { days of } \\
\text { proposit. } \\
\text { future }\end{array}$ & $\begin{array}{l}2 \text { days of } \\
\text { situat. } \\
\text { future and } \\
5 \text { days of } \\
\text { proposit. } \\
\text { future }\end{array}$ \\
\hline$\%$ of "yes" & $66.7 \%$ & $50.0 \%$ & $36.7 \%$ & $57.5 \%$ & $25.8 \%$ & $45.8 \%$ & $34.2 \%$ \\
\hline $\begin{array}{l}\text { Size of } \\
\text { framing } \\
\text { effect }\end{array}$ & - & \multicolumn{2}{|c|}{$\Delta=13.3 \%$} & \multicolumn{2}{|c|}{$\Delta=31.7 \%$} & \multicolumn{2}{|c|}{$\Delta=11.6 \%$} \\
\hline$\chi^{2,} d f, p$ & - & \multicolumn{2}{|c|}{$\begin{array}{c}\chi^{2}=4.34, d f=1 \\
p=.037\end{array}$} & \multicolumn{2}{|c|}{$\begin{array}{c}\chi^{2}=24.7, d f=1 \\
p<.001\end{array}$} & \multicolumn{2}{|c|}{$\begin{array}{c}\chi^{2}=3.4, d f=1 \\
p=.065\end{array}$} \\
\hline
\end{tabular}


to save money in any future situation, when it is not necessary to wait for the beginning of the sale. The existing literature suggests that hyperbolic discounting occurs primarily when time is described as a delay. But some researchers (Pender, 1996; Read \& Roelofsma, 2003, experiment 2; Read et al., 2005 , experiment 5) have shown that hyperbolic discounting has not been observed when the waiting time is given in terms of calendar dates, which, in our opinion, could also be interpreted as a kind of situational future.

The third hypothesis supposes that the combination of both temporal processes (situational and propositional), within one decision problem, alsoallows for their distinguishing. Two experimental conditions were introduced when the 7 days-time-distance was divided into $5+2$ days. Under one condition the composition of temporal processes was as follows: 5 days of situational future and 2 days of propositional future. Under the other condition it was: 5 days of propositional future and 2 days of situational future. According to the results (Table 2), the percentage of positive responses can be described by the inequality: YES(2 days Sit. +5 days Propos.) $<$ YES(5 days Sit. +2 day Propos.). But the significance of this difference seems to be marginal, $\chi^{2}=3.4, d f=1, p=.065$.

Read (2001) raises the question whether time-discounting is hyperbolic or subadditive. Subadditive time discounting means that discounting over a delay is greater when the delay is divided into subintervals (e.g., $7=5+2$ ) than when it is left undivided (e.g., 7 days waiting straightaway). It is necessary to point out that the subadditive effect is to be expected when one and the same temporal process is employed at divided and nondivided time distance. In our case, the prob- ability to receive the proposed amount of money is equal for all experimental conditions, $p=1.0$. So, the expected utility of the money saved is a function of the value it will have when it is received. The delay between the moment of decision-making and the moment of receipt equals to 7 days in divided and in undivided conditions. Considering that the situational discounting is less than the propositional, for a situational time flow the percentage of "yes" responses confirms our expectation of an effect, which is similar to the subadditive effect: YES(7 days sit.) > YES(2 days sit. +5 days propos. $), \chi^{2}=13.1$, $d f=1, p<.001$; YES(7 days sit.) $>$ YES ( 5 days sit. +2 day propos.), $\chi^{2}=3.27, d f=1$, $p=.07$. But for the propositional time flow the expectation was opposite: YES(7 days propos. $)<\mathrm{YES}$ (5 days sit. +2 day propos.), $\chi^{2}=10.44, d f=1, p=.001$; and $\operatorname{YES}(7$ days propos. $)<\mathrm{YES}(2$ days sit. +5 days propos.), $\chi^{2}=1.98, d f=1, p=.159$. This finding is not in line with the subadditive effect (Read, 2001), but confirms the idea about the essential discrepancy between the cognitive representations for the situational and propositional time flows.

There is another demonstration of the discrepancy of these two temporal processes. The loss of proposition attractiveness was calculated for each temporal process for one day of waiting. Simplifying, we assume that the attractiveness of a saving proposition declines almost linearly at the interval between the present time and the moment of the composed future in 7 days. Thus, the system of equations describes the contribution of each of the subjective time flows to the loss of saving proposition attractiveness. The percentage of positive responses under the present time condition $(66.7 \%)$ is taken as base-line. 
$5 \mathrm{~S}+2 \mathrm{P}=66.7-45.8=20.9 \%$

$2 S+5 P=66.7-34.2=32.5 \%$, where $S$ means a loss of proposition attractiveness by impact of situational time flow for 1 day and $P$ means that by propositional time flow. The solution of these equations gives: $S=$ $1.9 \% / d a y$ and $P=5.7 \% / d a y$. It is obvious that the recalculation of the decline of proposition attractiveness according to each of the hyperbolic ${ }^{4}$ or exponential discounting function $\left(\mathrm{V}=\mathrm{Ae}^{\mathrm{kD}}\right)$ will result in different discounting rates for situational and propositional temporal process. Considering the arguments for the correctness of the first and the second hypothesis, and the tendency to be correct in the case of the third hypothesis, we argue that the cognitive representations for the situational and propositional time flows are different.

For further clarification of the gender effect, two conditions, namely uninterrupted 4 days and 7 days future, were merged together, building two bigger samples of subjects for situational and propositional future. The results show that the temporal framing effect is not sensitive to the gender, at least for this type of commodity. Under the situational future time condition the male sub-

\footnotetext{
4 Frederick, Loewenstein, and O'Donoghue (2002) list the most common hyperbolic discount functions: (1) $D(t)=l / t$, where $t$ equals the length of delay (Ainslie, 1975); (2) $D(t)=1 /(1+k t)$, where $k$ equals the discount rate (Herrnstein, 1981; Mazur, 1987); (3) $D(t)=1 /(1+\alpha t)^{\gamma / \alpha}$, the generalized hyperbolic discount function, with $\alpha$, $\gamma>0$, where $\alpha$ determines "how much the function departs from constant discounting", and $\gamma$ is a time preference parameter positively related to the instantaneous discount rate (Loewenstein \& Prelec, 1992). But it makes no sense to make recalculations using all of them to show a quite obvious fact, that the rates of discount will be different for situational and propositional time flow.
}

jects gave $51.4 \%$ of positive responses and only $30.9 \%$ of positive responses under the propositional future time condition. The female subjects gave $57 \%$ of positive responses under the situational future time condition and only $34.1 \%$ of positive responses under the propositional future time condition. Taken separately for each gender, the temporal framing effect remains significant for male and female subjects, respectively $\chi^{2}=12.1, d f=1, p<0.001$, and $\chi^{2}=8.63$, $d f=1, p=0.003$. For the composed 7 days time distance, there was no difference for male and female subjects either. The gender effect on the responses given within the condition of situational time flow is not significant, $\chi^{2}<1$. The same was found for the gender effect for responses within the condition of propositional time flow, $\chi^{2}<1$. Thus, we may conclude that the second experiment shows no differences in the gender contribution to the manifestation of the temporal framing effect. But it is not to exclude that the role of gender depends on the gender specific attractiveness of commodity. Considering the wide range of the different services and commodities on the market, it would be an asset to repeat this study with other commodities, showing stronger gender attribution like a fishing rod vs. perfume, or going to a soccer game vs. a beauty salon.

\section{Discussion}

Depending on the task formulation, the human mind is able to develop different temporal representations of time flow. Two temporal processes in the future time mode show different features with regard to one and the same time distance and in relation to one and the same object (amount of money), so it 
essentially involves different temporal processes. When individuals activate the situational time flow, they are more "proximal" to the realization of the future perspective, and thus they agree to accept it with higher probability than when a propositional time flow is activated. This leads to the discrepancy in decision outcomes in mathematically equal propositions. Thus, the distinguishing feature of these two temporal processes is their impact on subjective value of the money proposed to be saved. Of course, this represents only a cognitive emulation of value change over time. The growing time distance also impacts the manifested discrepancy between these two temporal processes, resulting in a stronger framing effect. Possibly, there are other features that distinguish between the situational and propositional time flow. Thus, future experiments should concentrate on the specification of their properties regarding (a) relative and absolute amount of saving, (b) the first-person- and the third-person-perspective on a saving proposition, and (c) a gender effect. Such specification should contribute to further development of the idea about multiplicity of temporal processes (Polunin, 2011a).

The discrepancy we found between the situational and propositional time flows introduces an additional branch line in the classification of temporal processes, while the previous classification considers only the propositional processes (Polunin, 2011a). It is worth noticing here that similar temporal framing effect should be possible under other experimental conditions. Through a combination of different time distances and a parallel usage of situational and propositional time flow, one can induce temporal framing in the past time mode or even in the present time moment, despite the equality of abso- lute and relative savings in both propositions. Thus, it will be possible to compare the features of situational and propositional time flows in different time mode and on a wider set of intertemporal decision problems.

The above-described discrepancy in decision outcomes represents a new kind of temporal framing, which is to be distinguished from the previously described one (Loewenstein, 1988; Prelec \& Loewenstein, 1997). In our experiment no shifts in time distance between the tasks, no change in the order of time moments processing, no speeding up, and no different time horizons were used. Loewensten and Prelec (1992) in their paper "Anomalities in intertemporal choice: evidence and an interpretation" have listed a number of deviations in intertemporal decision outcomes, but none of them described such a phenomenon as the temporal framing described here. Up to a certain level, the described difference between situational and propositional futures is comparable to the "date/delay effect" discussed by Read et al. (2005). They use two ways to describe the moments at which outcomes will occur: as a delay from the present, or as a specific point in time identified by a calendar date. The "date/delay effect" also represents an anomaly in intertemporal choice, which means that the discount rates that are imputed when time is described using calendar dates (e.g., on September 29) are essentially lower than those revealed when future outcomes are given in terms of the corresponding delay (e.g., in four months). According to Read et al. (2005), the discount less when time is described as a calendar date than when it is described in terms of units of delay. In our studies the situational future also leads to weaker decline of proposition attractiveness. So, in some sense, the situational future 
seems to be similar to the future outcome identified by a calendar date. But our experimental design explicitly highlights the time distance between the present and the future time moment in both task-wordings, which is not the case in the study by Read et al. (2005).

The temporal framing effect is potentially useful for modelling of consumer decisions in future time mode and for an improvement of advertising of saving propositions. The discrepancy in processing of situational and propositional savings points lies in the fact that the elicited present value of an amount of money $X$ at the future time moment $t$ essentially differs depending on the activated temporal process. This could be of relevance for the promotion of future life securities and insurances. Obviously, money is not the only value in human life. Further developing the idea about the multiplicity of temporal processes can be applied to other values in human life.

The current findings as well as the idea about the mind's ability to develop a multitude of different cognitive representations for time flow (Polunin, 2011a) challenge the conventional time concept within social sciences. The conventional way of thinking about time assumes that time is a kind of receptacle, where everything happens and decisions are made as well. Our subjects, too, seem to underlie this conventionality. But this is not the only way to think about time. Ariely and Zakay (2001) believe that "time is a dimension in which all living organisms adjust to their environment", however, we see it from a slightly different perspective. Time is a basic category developed by the cognitive system itself for modelling of an environment and, thus, it serves to modulate behavior and accordingly improves the adjustment to the environment. It is more probable to survive in an environment, which is modelled through a number of basic categories like time, space, power, value, etc., than in one which has no such descriptions at all, and therefore seems absolutely alien and unpredictable. Such descriptions of the environment allow for at least subjectively secure acting, as long as the subject follows his/her own descriptions of the world. Later, based on the gained experience, the more successful descriptions of the environment survive, are improved and transmitted further. Therefore, we conceptualize time processing as kind of cognitive controlling, which helps to shape human behavior. That is the virtue of the introduction of basic categories in world-description by the cognitive system. When for Ariely and Zakay (2001) "time is medium within which decisions take place", for us time is an instrument constructed by the cognitive system to help itself in making decisions. The multitude of time representations provides a variability of responses to one and the same stimuli, that is distant in time, and this helps to avoid the blind alley in behavior. This explains why human mind can have more than one representation of time flow for one and the same time interval.

Some authors (Soman et al., 2005, also in overview by Frederick et al., 2002), analyzing the anomalies in intemporal decision making, have raised the question whether individuals are a bundle of multiple temporal selves. Our idea about the multitude of temporal processes avoids additional difficulties related to the definition of self, self-identity and the consequent philosophical questions. Possibly, some of the anomalies in intemporal decision-making are due to the multitude of cognitive representations for 
time flow that are applied depending on the context of the task. Why should human mind not be able to have a few representations for time flow, employing each of them quite independently? For space it develops two representations - egocentric and allocentric. Even more simple objects, like a guitar, can have more than one actual representation, once as a stringed instrument and once as a percussive instrument. Thus, time can be also represented from a variety of perspectives (Polunin, 2011a, 2013). The experimentally proved thesis about the multitude of cognitive representations of time flow should contribute to the re-conceptualization of time role in intertemporal decision-making and in relevant economic models requiring some changes in the conventional formulas.

Received February 6, 2014

\section{REFERENCES}

Ariely, D., Zakay, D. (2001). A timely account of the role of duration in decision making. Acta Psychologica, 108, 187-207.

Bell, D. E. (1982). Regret in decision making under uncertainty. Operations Research, 30, 961981

Block, R. A., Reed, M. A. (1978). Remembered duration: Evidence for a contextual-change hypothesis. Journal of Experimental Psychology: Human Learning and Memory, 4, 656-665.

Block, R. A. (1990). Cognitive models of psychological time. Hillsdale, NJ: Lawrence Erlbaum Associates.

Block, R. A., Zakay, D. (1997). Prospective and retrospective duration judgments: A meta-analytic review. Psychonomic Bulletin \& Review, 4 (June), 184-197.

Block, R., Zakay, D. (1996). Models of psychological time revisited. In $\mathrm{H}$. Helfrich (Ed.), Time and Mind (pp. 171-195). Seattle, Toronto, Göttingen, Bern: Hogrefe \& Huber Publishers.

Brown, S. W. (1997). Attentional resources in timing: Interference effects in concurrent temporal and nontemporal working memory tasks. Perception and Psychophysics, 59, 1118-1140.
Chandran, S., Menon, G. (2004). When a day means more than a year: Effects of temporal framing on judgments of health risk. Journal of Consumer Research, 31(2) (September 2004), 375 389.

Fraisse, P. (1985). Psychologie der Zeit. München: Reinhardt Verlag. (original published 1957: Psychologie du temps).

Frederic, S., Loewenstein, G., O’Donoghue, T. (2002). Time discounting and time preference: A critical review. Journal of Economic Literature, 40(2), 351-401.

Kahneman, D., Tversky, A. (1979). Prospect Theory: An analysis of decision under risk, Econometrica, 47(2), 363-391.

Kühbinger, A. (1998). The influence of framing on risky decisions: A meta-analysis. Organizational Behaviour and Human Decision Process, 75(1), 23-55.

Levin, I. P., Schneider, S. L., Gaeth, G. J. (1998). All frames are not created equal: A typology and critical analysis of framing effects. Organizational Behaviour and Human Decision Process, 76(2), 149-188.

Liberman, N., Trope, Y. (1998). The role of feasibility and desirability considerations in near and distant future decisions: A test of Temporal Construal Theory. Journal of Personality and Social Psychology, 75 (July), 5-18.

Loewenstein, G. F. (1988). Frames of mind in intertemporal choice. Management Science, 34(2), 200-214.

Loewenstein, G., Prelec, D. (1992). Anomalities in intertemporal choice: Evidence and an interpretation. The Quarterly Journal of Economics, 107(2), 573-597.

Loewenstein, G., Elster, J. (Eds.) (1992). Choice over time. NY: Russell Sage Foundation.

Markowitz, H. (1952). The utility of wealth. Journal of Political Economy, 60(2), 151-158.

Mazur, J. (1987). An adjustment procedure for studying delayed reinforcement. In M. Commons, J. Mazur, J. Nevin, \& H. Raiffa (Eds.), The effect of delay and intervening events on reinforcement value (pp. 55-73). Hillsdale, NJ: Lawrence Erlbaum.

Pender, J. L. (1996). Discount rates and credit markets: Theory and evidence from rural India. Journal Development Economics, 50(2), 257 296.

Polunin, O. (2009). Temporal dimension of the framing effect in topical mental accounting. Studia Psychologica, 51(4), 343-355. 
Polunin, O. (2011a). Temporal processes in the topical mental accounting. Studia Psychologica, 53(3), 275-291.

Polunin, O. (2011b). Relative amount of monetary saving as a factor of proposition aging and elimination of the framing effect. Studia Psychologica, 53(4), 327-338.

Polunin, O. (2010). Temporal framing of electoral decision: An aging of subject and an aging of proposition. Scientific Studies on Social and Political Psychology. Kyiv: Melenium, 28(31), 297-311. (in Ukrainian)

Polunin, O. (2013). Aging of monetary saving proposition formulated from the first- and the third-person perspective as factor modulating the framing effect. Studia Psychologica, 55(2), 123138.

Prelec, D., Loewenstein, G. (1997). Beyond time discounting. Marketing Letters, 8, 97-108.

Read, D. (2001). Is time-discounting hyperbolic or subadditive? Journal of Risk and Uncertainty, 23(1), 5-32.

Read, D., Roelofsma, P. H. M. P. (2003). Subadditive versus hyperbolic discounting: A comparison of choice and matching. Organizational Behavior and Human Decision Processes, 91, 140-153.

Read, D., Frederick, S., Burcu Orsel, B., \& Rahman, J. (2005). Four score and seven years from now:
The date/delay effect in temporal discounting. Management Science, 51(9), 1326-1335.

Samuelson, P. (1937). A note on measurement of utility. Review of Economic Studies, 4, 155161.

Soman, D., Ainslie, G., Frederick, S., Li, X., Lynch, J., Moreau, P., Mitchell, A., Read, D., Sawyer, A., Trope, Y., Wertenbroch, K., Zauberman, G. (2005). The psychology of intertemporal discounting: Why are distant events valued differently from proximal ones? Marketing Letters 16(3/4), 347-360.

Thomas, E. A. C., Weaver, W. B. (1975). Cognitive processing and time perception. Perception \& Psychophysics, 17, 363-367.

Trope, Y., Liberman, N. (2000). Temporal construal and time-dependent changes in preference. Journal of Personality and Social Psychology, 79 (December), 876-89.

Tversky, A., Kahneman, D. (1981). The framing of decisions and the psychology of choice. Science, 211, 453-458.

Wearden, J. H. (2002). Applying the scalar timing model to human time psychology: Progress and challenges. In H. Helfrich (Ed.), Time and mind II: Information processing perspectives (pp. 21 39). Seattle, Toronto, Göttingen, Bern: Hogrefe \& Huber Publishers.

\title{
KOGNITÍVNA REPREZENTÁCIA SITUAČNÉHO A PROPOZIČNÉHO PLYNUTIA ČASU AKO ZÁKLAD ČASOVÉHO EFEKTU RÁMCOVANIA V BUDÚCOM ČASOVOM MÓDE
}

\author{
O. P o l u n in
}

Súhrn: Štúdia uvádza zistenia o novom druh časového efektu rámcovania, uplatňovanom pri návrhoch finančnej úspory. Na základe našich predchádzajúcich zistení o viacnásobných kognitívnych reprezentáciách plynutia času (Polunin, 2009, 2011, 2013), sme uvažovali o dvoch časových procesoch - situačnom a propozičnom plynutí času. Každý z časových procesov má špecifické charakteristiky a v rôznej miere vplýva na zhodnotenie navrhnutej peňažnej úspory. O návrhu finančnej úspory sa participanti rozhodovaliv dvoch experimentoch. Napriek rovnakej vzdialenosti od začiatku možnej úspory a rovnakej úspore peňazí vzniká časový efekt rámcovania. Participanti sa rozhodovali signifikantne odlišne v závislosti od toho, či sa aktivovalo situačné alebo propozičné plynutie času. Pri prvom dochádza k pomalému poklesu pozitívnych odpovedí na návrh úspory, zatial' čo pri druhom návrhu úspory dochádza k výraznej strate jeho prít’ažlivosti. 